\title{
Downregulation of GSK3 $\beta$ by miR-544a to maintain self-renewal ability of lung caner stem cells
}

\author{
XIAO-MEI MO ${ }^{1,2^{*}}$, HUA-HUI LI ${ }^{3,4^{*}}$, MING LIU ${ }^{1}$ and YAN-TUAN LI ${ }^{1}$ \\ ${ }^{1}$ Key Laboratory of Marine Drugs, Ministry of Education, School of Medicine and Pharmacy, \\ Ocean University of China, Qingdao, Shandong 266003; ${ }^{2}$ Pharmacy Department, \\ Qingdao Women and Children Hospital; ${ }^{3}$ Medical College of Qingdao University; \\ ${ }^{4}$ Department of Laboratory Medicine of Qingdao Municipal Hospital, Qingdao, Shandong 266011, P.R. China
}

Received December 2, 2013; Accepted July 1, 2014

DOI: $10.3892 / \mathrm{ol} .2014 .2387$

\begin{abstract}
In order to study the influence and mechanism of miR-544a on the self-renewal ability of lung cancer stem cells, TargetScan was used to predict the target gene of miR-544a. A luciferase reporter system and western blotting were used to validate the target genes identified by TargetScan. 95C and 95D low and high metastatic human lung cancer cells were transfected with miR-544a, and quantitative polymerase chain reaction (qPCR) was used to verify the miR-544a expression in these two cell lines. Tumor ball (spheroid) suspension culture was use to study the effects of miR-544a on lung cancer stem cells. TargetScan predicted that miR-544a interacted with GSK3 $\beta$. A luciferase reporter system $(\mathrm{F}=201.37, \mathrm{P}<0.01)$ and western blot analysis was used to validate that miR-544a could inhibit the expression of GSK3 $\beta$, while $\beta$-catenin and CD133 were significantly increased in miR-544a-overexpressing 95C and 95D cells ( $\mathrm{F}=9.43,7.73$ and 3.37, respectively; $\mathrm{P}<0.01$ ). qPCR revealed that miR-544a was overexpressed in transfected 95C and 95D cells (20.51 \pm 0.97 and 15.16 \pm 1.38 , respectively; $\mathrm{F}=418.05 ; \mathrm{P}<0.01)$. miR-544a-overexpressing cells formed spheroids in suspension cultures of spheroid single cells. miR-544a was shown to reduce the expression of GSK $3 \beta$ and activate the Wnt signaling pathway to maintain the self-renewal ability of lung caner stem cells.
\end{abstract}

\section{Introduction}

Tumor metastasis can occur despite radiation and chemotherapy treatment. Non-small cell lung carcinoma (NSCLC) comprises

Correspondence to: Dr Yan-Tuan Li, Key Laboratory of Marine Drugs, Ministry of Education, School of Medicine and Pharmacy, Ocean University of China, 5 Yu-Shan Road, Qingdao 266003, P.R. China

E-mail: yantuanli@ouc.edu.cn

*Contributed equally

Key words: non-small cell lung cancer, cancer stem cells, GSK3 $\beta$, Wnt signaling pathway, miR-544a
$80 \%$ of all types of lung cancer, and a number of cancer patients succumb to cancer metastasis (1). Therefore, further investigation with regard to the mechanism of metastasis in NSCLC is required. A previous study has shown that tumor stem cells (TSC) may be responsible for cancer recurrence and metastasis (2). TSCs have the ability to eliminate chemotherapy drugs from the cell, resulting in its multi-drug resistance (3). TSCs can also activate the DNA mismatch repair system to resist damage induced by radiation (4). In order to reduce tumor recurrence and metastasis, it is necessary to determine the mechanisms of TSC.

There are numerous signaling pathways involved in the formation of TSCs, including the Wnt pathway (5) which involves miRNAs. The mature miRNAs consist of 22 nucleotides, and as negative regulators of gene expression, predominantly recognize the complementary sequences in the $3^{\prime}$ untranslated regions (UTRs) of their target messenger RNAs (6).

95C and 95D cells are NSCLC cell lines, with different metastatic abilities. The effects of miR-544a were studied in 95C and 95D cells in order to reveal the mechanism of GSK3 $\beta$ downregulation, an inhibitory factor of the Wnt pathway (7). The present study aimed to determine the function of miR-544a in the formation of TSCs.

\section{Materials and methods}

Bioinformatic analysis. The miR-544a target gene, GSK3 $\beta$, was predicted using TargetScan software (http://www. targetscan.org/). The results showed that miR-544a was highly likely to interact with GSK3 $\beta$ (Fig. 1).

Luciferase assays. Light Switch luciferase assay reagents were obtained from Promega (Promega Corporation, Madison, WI, USA). miRNA negative control (NC) and miR-544a mimic (MC) were transfected together with GSK3 $\beta$ 3' UTR or GSK3 $\beta$ mutated (MUT) 3'UTR, respectively, into HEK293T cells obtained from the American Type Culture Collection (Manassa, VA, USA) for $24 \mathrm{~h}$ according to the manufacturer's instructions (Promega Corporation). Expression of Firefly (FLUC) and Renilla Luciferase (RLUC) was counted using a luminometer (Promega). Luciferase expression was given as the relative light units (RLUC/LUC) to determine whether GSK $3 \beta$ was the target of miR-544a in vitro. 
Transfection. A retroviral vector pBaBe-puro (Addgene, Cambridge, MA, USA) expressing miR-544a was constructed and then inoculated into HEK293T cells for $24 \mathrm{~h}$. The reagents were added to a $1.5 \mathrm{ml}$ Eppendorf tube, including $20 \mu \mathrm{g}$ PIK, $20 \mu \mathrm{g}$ expression plasmid, $110 \mu \mathrm{l}$ $\mathrm{ddH}_{2} \mathrm{O}, 250 \mu \mathrm{l} \mathrm{CaCl}$ and $200 \mu \mathrm{l}$ hepes-buffered saline. The viruses were harvested $24 \mathrm{~h}$ after transfection. 95C and 95D cells (American Type Culture Collection) were subsequently infected by these viruses and the cells with highest levels of miR-544a were screened using a puromycin marker. Quantitative polymerase chain reaction (qPCR) was used to identify these cells.

$q P C R$. Total RNA was extracted from 95C, 95D, miR-544a-95C and miR-544a-95D cells using TRIzol ${ }^{\mathrm{TM}}$ reagent (Invitrogen Life Technologies, Carlsbad, CA, USA) and reverse-transcribed to cDNA using M-MLV reverse transcriptase (Toyobo Co. Ltd., Osaka, Japan). qPCR was performed using a PCR Detection System (Bio-Rad, Hercules, CA, USA) with the use of SYBR ${ }^{\circledR}$ Green I Premix Ex Taq (Takara Bio, Inc., Shiga, Japan). Specific primers for miR-544a were designed by Rui Bo Company (Guangzhou, China). The qPCR reaction was set up as follows: $10 \mu \mathrm{l} 2 \mathrm{X}$ SYBR Green I, $0.25 \mu 110 \mathrm{pmol} / 1$ primers, $1 \mu \mathrm{l} \mathrm{cDNA}$ and $\mathrm{ddH}_{2} \mathrm{O}$. The reaction protocol included an initial step of $120 \mathrm{sec}$ at $95^{\circ} \mathrm{C}$. Each PCR cycle involved denaturation $\left(95^{\circ} \mathrm{C}\right.$, $30 \mathrm{sec})$, annealing $\left(60^{\circ} \mathrm{C}, 35 \mathrm{sec}\right)$ and extension $\left(72^{\circ} \mathrm{C}, 20 \mathrm{sec}\right)$ for 40 cycles, and the fluorescence was measured at each cycle. The relative fold change of expression of miR-544a was quantified as $2^{-\Delta \Delta} \mathrm{Ct}$, where $\Delta \Delta \mathrm{Ct}$ was $\mathrm{Ct}$ (target gene) - $\mathrm{Ct}$ (housekeeping gene). Small nuclear RNA U6 was used as a housekeeping gene. The U6 primer sequence was as follows: Forward, 5'-TGGCACCCAGCACAATGAA-3'; and reverse, 5'-CTAAGTCATAGTCCGCCTAGAAGCA-3'.

Western blotting. 95C, 95D, miR-544a-95C and miR-544a-95D cells were lysed by radioimmunoprecipitation assay buffer. The protein concentration was detected by bicinchoninic acid assay (BCA). Protein $(20 \mu \mathrm{g})$ was loaded onto a $120-\mathrm{g} / 1$ SDS-PAGE gel and the proteins were separated at $120 \mathrm{~V}$ for $1.5 \mathrm{~h}$. The proteins were then transferred to a polyvinylidene fluoride membrane on ice at $100 \mathrm{~V} 1 \mathrm{~h}$, and then the membrane was blocked using 5\% skimmed milk powder for $2 \mathrm{~h}$ at room temperature. The membranes were probed with primary monoclonal rat anti-human GSK3 $\beta$ (Abcam, Cambridge, MA, USA), $\beta$-catenin (Abcam), CD133 (Epitomics, Burlingame, CA, USA) and $\alpha$-Tubulin (Santa Cruz Biotechnology Inc., Santa Cruz, CA, USA) antibodies $(1: 10,000)$, as well as a monoclonal rabbit anti-rat $\operatorname{IgG}$ secondary horseradish peroxidase (HRP) antibody (Santa Cruz Biotechnology Inc.). Protein expression was quantitatively assessed using an HRP-enhanced chemiluminesence scanner (LAS-4000 mini luminescent imaging analyzer; Fijifilm, Tokyo, Japan)

Spheroid culture. 95C, 95D, miR-544a-95C and miR-544a-95D cells were digested with $0.25 \%$ pancreatic enzyme, and 1,000 cells $/ \mathrm{ml}$ were resuspended in RPMI-1640 serum-free medium. RPMI-1640 media was supplemented with 1X B27 (Gibco-BRL, ), $20 \mathrm{ng} / \mathrm{ml}$ EGF (BD Biosciences), $0.4 \%$ bovine
Table I. Validation of miR-544a target gene by luciferase assay.

\begin{tabular}{lc}
\hline Groups & RLUC/FLUC \\
\hline miR-544a mimic+GSK3 $\beta$ 3'UTR & $0.52 \pm 0.01$ \\
miR-544a mimic+GSK3 $\beta$ MUT3'UTR & $1.01 \pm 0.02^{\mathrm{a}}$ \\
miR-544a-NC+GSK3 $\beta$ 3'UTR & $1.04 \pm 0.05^{\mathrm{b}}$ \\
miR-544a-NC+GSK3 $\beta$ MUT3'UTR & $1.07 \pm 0.03^{\mathrm{c}}$ \\
F-value & 201.37 \\
P-value & $<0.01$
\end{tabular}

Data represent the mean \pm standard deviation, $\mathrm{n}=9$. ${ }^{\mathrm{a}} \mathrm{q}=491.05$; ${ }^{\mathrm{b}} \mathrm{q}=517.56 ;{ }^{\mathrm{c}} \mathrm{q}=547.93, \quad \mathrm{P}<0.01$ as compared with miR-544a mimic+GSK3 $\beta$ 3'UTR. 3'UTR, 3' untranslated region; NC, negative control; miR, microRNA.

Table II. Quantitative polymerase chain reaction analysis of miR-544a in 95C and 95D human lung cancer cells.

\begin{tabular}{lc}
\hline Groups & $2^{-\Delta \Delta \mathrm{CT}}$ \\
\hline $95 \mathrm{C} \mathrm{NC}$ & $1.00 \pm 0.00$ \\
$95 \mathrm{C}+\mathrm{miR}-544 \mathrm{a}$ & $20.51 \pm 0.97^{\mathrm{a}}$ \\
$95 \mathrm{D} \mathrm{NC}$ & $1.00 \pm 0.00$ \\
$95 \mathrm{D}+\mathrm{miR}-544 \mathrm{a}$ & $15.16 \pm 1.38^{\mathrm{b}}$ \\
\hline
\end{tabular}

Data represent the mean \pm standard deviation, $\mathrm{n}=9$. ${ }^{\mathrm{a}} \mathrm{q}=19.51, \mathrm{P}<0.01$ as compared with $95 \mathrm{C} \mathrm{NC}$; ${ }^{\mathrm{b}} \mathrm{q}=14.16, \mathrm{P}<0.01$ as compared with $95 \mathrm{D}$ NC. NC, negative control; miR, microRNA; 95C, low metastatic human lung cancer cells; 95D, high metastatic human lung cancer cells.

serum albumin and $4 \mathrm{mg} / \mathrm{ml}$ insulin (Sigma-Aldrich). Upon formation of single cell proliferates to spheroids, the spheroids were digested with $0.25 \%$ pancreatic enzyme and cultivated as previously described.

Statistical analysis. One-way analysis of variance with SNK-q test for multiple comparisons was used to analyze the appropriate data using SPSS 15.0 software (SPSS, Inc., Chicago, IL, USA). Data are shown as the mean \pm standard deviation. $\mathrm{P}<0.05$ was considered to indicate a statistically significant difference.

\section{Results}

Validation of miR-544a target gene by luciferase assay. As shown in Table I, luciferase assays revealed that the miR-544a mimic can interact and inhibit the expression of GSK3 $\beta$ 3'UTR $(0.52 \pm 0.01)$. The miR-544a mimic could not interact with and inhibit the expression of the GSK3 $\beta$ MUT 3'UTR, and the expression of reporter gene $(1.01 \pm 0.02)$ increased $(q=491.05, \mathrm{P}<0.01)$.

Identification of cells stably expressing miR-544a, by qPCR. The expression level of 95C NC and 95D NC was normalized to $1.00 \pm 0.00$. Following transfection with miR-544a, 
Table III. Analysis of protein expression in members of the Wnt pathway.

\begin{tabular}{lccc}
\hline Groups & $\beta$-catenin & CD133 & GSK3 $\beta$ \\
\hline $95 \mathrm{C} \mathrm{NC}$ & $0.467 \pm 0.010$ & $0.000 \pm 0.000$ & $0.278 \pm 0.013$ \\
$95 \mathrm{C}+$ miR-544a & $0.966 \pm 0.009^{\mathrm{a}}$ & $0.660 \pm 0.007^{\mathrm{a}}$ & $0.003 \pm 0.003^{\mathrm{a}}$ \\
$95 \mathrm{D}$ NC & $0.656 \pm 0.006$ & $0.013 \pm 0.006$ & $0.205 \pm 0.009$ \\
$95 \mathrm{D}+$ miR-544a & $1.489 \pm 0.022^{\mathrm{b}}$ & $0.472 \pm 0.007^{\mathrm{b}}$ & $0.008 \pm 0.003^{\mathrm{b}}$ \\
F-value & 7.73 & 3.37 & 9.43 \\
P-value & $<0.01$ & $<0.01$ & $<0.01$ \\
\hline
\end{tabular}

Data represent the mean \pm standard deviation, $\mathrm{n}=9 .{ }^{\mathrm{a}} \mathrm{q}=49.27,66.00,2.75, \mathrm{P}<0.01$ as compared with $95 \mathrm{C} \mathrm{NC} ;{ }^{\mathrm{b}} \mathrm{q}=83.28,45.84,1.95, \mathrm{P}<0.01$, as compared with 95D NC. NC, negative control; miR, microRNA; 95C, low metastatic human lung cancer cells; 95D, high metastatic human lung cancer cells.

\section{G SK3B-3'UTR-mu 5' _AUUGAAAAUUG AGCUUGAUACG A_3' hsa-miR544a 3' CUUGAACG AUUUUUACGUCUUA 5' I I II | | I |} Position 1064-1071 of G SK3B-3'UTR 5' _AUUGAAAAUUG AGCUUGCAGAAA_3'

Figure 1. miR-544a can combine with the 3'UTR of GSK3 $\beta$. miR, microRNA; 3'UTR, 3' untranslated region.

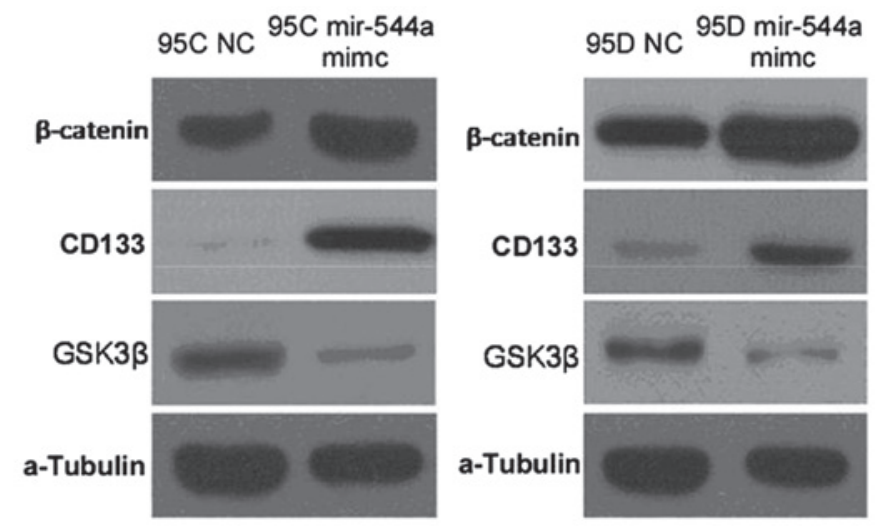

Figure 2. Western blot analysis of protein expression in the Wnt pathway. NC, negative control; mimc, mimic combine; miR, microRNA; 95C, low metastatic human lung cancer cells; 95D, high metastatic human lung cancer cells.

the miR-544a expression level of $95 \mathrm{C}$ and $95 \mathrm{D}$ cells was $20.51 \pm 0.97$ and $15.16 \pm 1.38$, respectively $(\mathrm{F}=418.05, \mathrm{P}<0.01)$, among all four groups. As compared with that of the pre-transfection, the expression level was significantly increased ( $q=19.51$ and 14.16, respectively, both $\mathrm{P}<0.01)$ (Table II).

Expression level of proteins of the Wht pathway by western blotting. According to the western blot analysis, the level of GSK $3 \beta$ reduced, but that of $\beta$-catenin and CD133 increased in $95 \mathrm{C}$ and $95 \mathrm{D}$ cells transfected with miR-544a. It was therefore concluded that miR-544a activated the Wnt pathway (Fig. 2 and Table III).

Effect of miR-544a on spheroid formation. Spheroid culture showed that cells stably expressing miR-544a (95C+miR-544a or 95D+miR-544a) had an increased tendency to form tumor spheroids (Fig. 3).
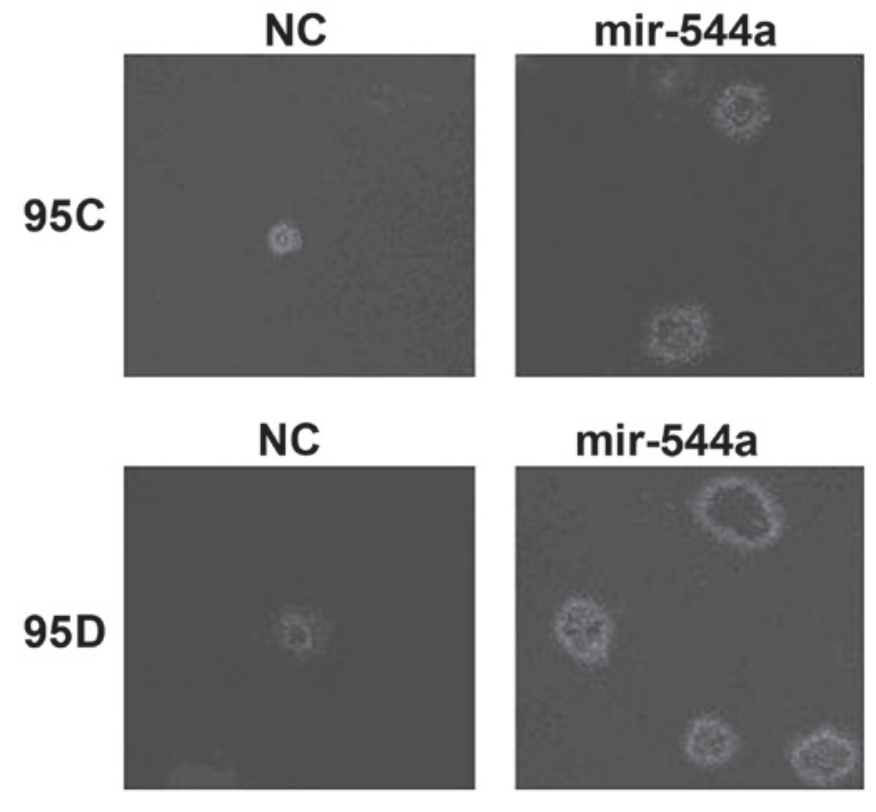

Figure 3. Impact of miR-544a in spheroid formation (magnification, x200). NC, negative control; mir, microRNA; 95C, low metastatic human lung cancer cells; 95D, high metastatic human lung cancer cells.

\section{Discussion}

The canonical Wnt pathway is the most well-known and characterized Wnt signaling pathway (8). In the absence of a Wnt ligand binding to its receptor complex, $\beta$-catenin is targeted for degradation and the Wnt pathway is shutdown. When the level of $\beta$-catenin increases, the Wnt pathway is activated and subsequently the downstream target genes are also activated (9). GSK3 $\beta$ is the most important inhibitory factor in the Wnt pathway. Mutations to or downregulation of GSK3 $\beta$ can lead to the activation of the Wnt pathway and self-renewal (10). 
While TSCs have an important role in tumor recurrence and metastasis, TSCs have the ability of eliminate chemotherapeutics from cells, therefore resulting in multi-drug resistance of tumor cells (3); TSCs can also activate the DNA mismatch repair system to resist radiation damage (4).

miRNA participates in the development of numerous tumors. miR-544a has been shown to promote tumor invasion and metastasis (11). Other miRNAs, such as miR-34a, miR-107, miR-140 and miR-143 in glioma (12), colon (13), breast (14) and prostate cancer (15), respectively, have been shown to have an important role in TSC formation. Another study has revealed that the level of miR-874 in NSCLC TSCs reduced, leading to the loss of TSC self-renewal and CD133 on the TSC surface (16).

Bioinformatic analyses indicated that miR-544a targeted GSK3 $\beta$, an inhibitory factor of the Wnt pathway. Luciferase assays validated that miR-544a could interact with and inhibit the expression of GSK3 $\beta$. Western blot analysis revealed that in cells stably expressing miR-544a, the level of GSK3 $\beta$ was reduced, whereas the expression levels of $\beta$-catenin and CD133 were upregulated. To determine the impact of miR-544a in spheroid formation, a spheroid culture was established. It was observed that the cells stably expressing miR-544a had an increased tendency to form tumor CD133-positive spheroids.

In conclusion, miR-544a has an important function not only in tumor invasion and metastasis, but also in TSC formation. Abnormal expression of miR-544a leads to NSCLC self-renewal. Future studies will focus on the mechanism of miR-544a in the formation of TSCs, with a view to novel NSCLC treatment approaches.

\section{References}

1. Lam WK and Watkins DN: Lung cancer: future directions. Respirology 12: 471-477, 2007.
2. Lobo NA, Shimono Y, Qian D, et al: The biology of cancer stem cells. Annu Rev Cell Dev Biol 23: 675-699, 2007.

3. Dean M, Fojo T and Bates S: Tumor stem cells and drug resistance. Nat Rev Cancer 5: 275-284, 2005.

4. Lin CT, Lyu YL, Xiao H, et al: Suppression of gene amplification and chromosomal DNA integration by the DNA mismatch repair system. Nucleic Acids Res 29: 3304-3310, 2001.

5. Alamgeer M, Peacock CD, Matsui W, et al: Cancer stem cells in lung cancer: Evidence and controversies. Respirology 18: 757-764, 2013.

6. Vimalraj S, Miranda PJ, Ramyakrishna B and Selvamurugan N: Regulation of breast cancer and bone metastasis by microRNAs. Dis Markers 35: 369-387, 2013.

7. Trowbridge JJ, Xenocostas A, Moon RT and Bhatia M: Glycogen synthase kinase-3 is an in vivo regulator of hematopoietic stem cell repopulation. Nat Med 12: 89-98, 2006.

8. Paul I, Bhattacharya S, Chatterjee A and Ghosh MK: Current understanding on EGFR and Wnt/ $\beta$-catenin signaling in glioma and their possible crosstalk. Genes Cancer 4: 427-446, 2013.

9. Staal FJ, Luis TC and Tiemessen MM: WNT signalling in the immune system: WNT is spreading its wings. Nat Rev Immunol 8: 581-593, 2008.

10. Malanchi I, Peinado H, Kassen D, et al: Cutaneous cancer stem cell maintenance is dependent on beta-catenin signaling. Nature 452: 650-653, 2008.

11. Ma R, Zhang G, Wang H, et al: Downregulation of miR-544 in tissue, but not in serum, is a novel biomarker of malignant transformation in glioma. Oncol Lett 4: 1321-1324, 2012.

12. Sun L, Wu Z, Shao Y, et al: MicroRNA-34a suppresses cell proliferation and induces apoptosis in U87 glioma stem cells. Technol Cancer Res Treat 11: 483-490, 2012.

13. Bu P, Chen KY, Chen JH, et al: A microRNA miR-34a-regulated bimodal switch targets Notch in colon cancer stem cells. Cell Stem Cell 12: 602-615, 2013.

14. Li Q, Yao Y, Eades G, et al: Downregulation of miR-140 promotes cancer stem cell formation in basal-like early stage breast cancer. Oncogene 33: 2589-2600, 2014.

15. Fan X, Chen X, Deng W, et al: Up-regulated microRNA-143 in cancer stem cell differentiation promotes prostate cancer cells metastasis by modulating FNDC3B expression. BMC Cancer 13: 61-71,2013.

16. Kesanakurti D, Maddirela DR, Chittivelu S, et al: Suppression of tumor cell invasiveness and in vivo tumor growth by microRNA-874 in non-small cell lung cancer. Biochem Biophys Res Commun 434: 627-633, 2013. 